\title{
Of chemistry and conflict
}

\section{Alex Wellerstein commends a biography of James Conant, scientific 'cold warrior'.}

A lthough James B. Conant's imprint on US science was substantial, his name rings few bells outside his major domains of influence: chemistry, Harvard University and the atomic bomb. And from photographs of this boyish, reedy, bespectacled figure, one would scarcely guess his importance in at multiple key intersections of twentieth-century science and politics. Conant (1893-1978) was one of the first and most prominent scientistadministrators. Between the dawn of the First World War and the end of the cold war, this new breed of technical expert revolutionized the worlds of weaponry, education and governance.

Man of the Hour, by Conant's granddaughter Jennet Conant, is a fresh take on his life. And a welcome one: the most recent major biography was James Hershberg's 1993 James B. Conant: Harvard to Hiroshima and the Making of the Nuclear Age (Knopf). Jennet Conant is a seasoned biographer of scientists, including radar pioneer Alfred Loomis and nuclear physicist J. Robert Oppenheimer, as well as author of a study on a British spy ring in Washington DC during the Second World War. Like Hershberg's, her book is a doorstop; but Conant himself noted that he had lived "several lives".

In his first life, Conant was a successful chemist, an up-and-comer who lacked the refinement and pedigree of many of his undergraduate peers at Harvard, in Cambridge, Massachusetts; but he made up for it with talent and relentless ambition. His prowess in both organic and physical chemistry was rare at the time, rapidly making him a titan of research. Conant was one of a generation of US experts who began to put American science on the map, independent of European influence. At the advent of the First World War, Conant briefly attempted war profiteering by organizing an organicchemistry laboratory; that ended with an explosion and a colleague's death. Later, he oversaw the manufacture of a new poison gas, lewisite, at a secret factory near Cleveland, Ohio, in the US chemical-weapons programme. The war ended before it was used, but that foray into military work would not be his last.

In 1933, during his second life, Conant improbably for someone with such narrow technical expertise - became president of Harvard. He proved an able administrator, although his tenure was not without issues,

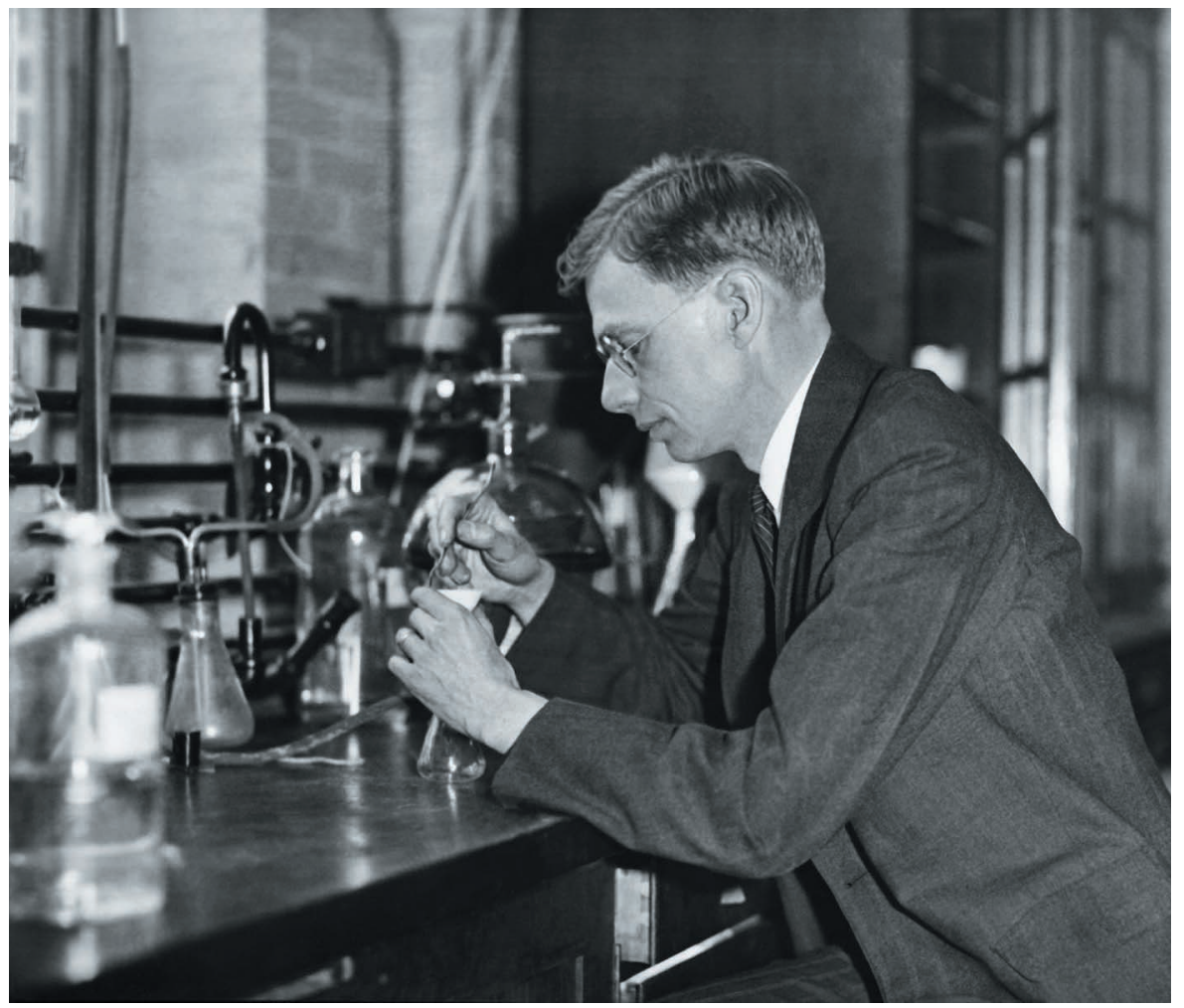

James Conant was a key figure at the intersection of science and politics — and in the Manhattan Project. such as unpopular attempts to reform the tenure process, and drubbings from colleagues and the press. With the rise of fascism an urgent concern, Conant strove for balance: he was passionate in defending democracy while counselling against before the United States entered the Second World War, he lobbied for better cooperation between science and government. $\mathrm{He}$ became an important partner to engineer Vannevar Bush, whose influence with President Franklin D. Roosevelt was such that new government organizations were created out of thin air. Conant helmed the chemistry section of Bush's National Defense Research Committee (NDRC) in 1940, and took over the body as a whole the next year, when it became an advisory board to the Office of Scientific Research and Development.

As NDRC head and a confidant of Bush's, Conant became intimately involved in the US effort to create an atomic bomb. The scientific credit for that typically goes to
Man of the Hour: James B. Conant, Warrior Scientist JENNET CONANT Simon \& Schuster: 2017. extremist positions of all sorts. In the lull hands-on researchers such as Oppenheimer, but Conant established many important structural elements of the Manhattan Project. He was first to suggest that the most secret research be concentrated in a remote laboratory (eventually narrowed down to Los Alamos, New Mexico). He approved almost every major administrative decision, including Oppenheimer's appointment as head of the lab. His was often the voice of scepticism and pragmatism, demanding hard evidence proving the project's worth. It was also he who suggested that the bomb be dropped on a Japanese military installation surrounded by workers' homes, leading ultimately to the selection of Hiroshima. He never expressed regret about that attack, although he privately expressed the belief that the Nagasaki strike was unnecessary, according to Hershberg. However, Conant and Bush both lobbied strongly for international nuclear-arms control, even during the war. Here he was less successful. In the late 1940s, as a major adviser to the administration of US President Harry Truman, he vocally opposed the hydrogen bomb, again without success. 
At the dawn of Dwight Eisenhower's presidency in 1953, Conant, now a seasoned educator and administrator, stepped into a third life as a high-profile political administrator. He became US high commissioner for Germany, helping the country to make the transition from occupation to autonomy. Conant had long thought of Germany as an exemplar of chemical work, education and cooperation between science, industry and governance, for good and ill. Adolf Hitler and other demagogues, he felt, had robbed it of its real potential. When West Germany became autonomous in 1955, Conant became its first US ambassador. In 1958, he returned to the United States, where he lobbied for educational reform through measures such as standardized testing, with some success. He continued to write on social issues, arguably straying outside his area of expertise, and ultimately authored 21 books on a range of topics. The New York Times proclaimed that his death at 84 left a "vacancy": there was "Conant was one of a generation of US experts who began to put American science on the map." no other educator as broad-minded in the country.

Unsurprisingly, Jennet Conant tends to interpret her grandfather's behaviour more sympathetically than does Hershberg. Take Conant's marriage to Grace Richards, the daughter of his Harvard supervisor, Nobel laureate Theodore Richards. Hershberg suggests this might have been a calculated professional move; Jennet Conant sees it as motivated purely by love and intellectual compatibility. Both seem plausible. In fact, comparing the two biographies allows a complementary understanding of the man, despite inevitable overlap. If you want to know about Conant as a "cold warrior", Hershberg's book contains much more of interest. Man of the Hour is stronger on the personal forces, talents and timing that propelled him into several positions of influence, perhaps in part because of the author's unfettered access to papers and personal sources.

Jennet Conant is a fine writer, and her biography emerges at a salutary moment. The story of James Conant's attempts to create a re-intellectualized US government and a better-educated public, and his vision of a shaping role for the United States in an everchanging world, are important reminders in an age of devalued expertise, educational crises and turbulent governance.

Alex Wellerstein is assistant professor of science and technology studies at the College of Arts and Letters of the Stevens Institute of Technology in Hoboken, New Jersey.

e-mail:awellers@stevens.edu

\section{Books in brief}

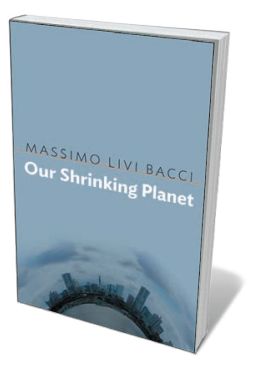

\section{Our Shrinking Planet}

Massimo Livi Bacci (Translated by David Broder) POLITY (2017)

In this authoritative, beautifully synthesized analysis of global population, demographer Massimo Livi Bacci pinpoints a planet-sized problem. When the "demographic timebomb" announced decades ago failed to detonate, complacency set in over creeping population growth. Now, 10 billion people are set to cram Earth by 2050, yet population is off most national agendas and has a secondary place in the United Nations Sustainable Development Goals. Bacci traces population patterns over ten millennia to reveal a squeezed present in which per capita living space has shrunk by a factor of 1,000 .

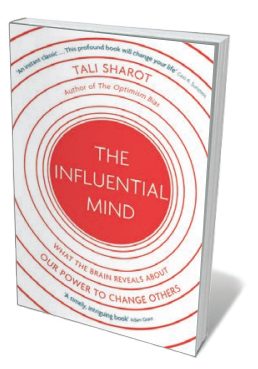

\section{The Influential Mind}

Tali Sharot LITTLE, BROWN (2017)

Advertising, politics, education - any juxtaposition of human and message involves influence. But why might a patently ill-informed demagogue sway more people than a scientist? In this perceptive study, cognitive neuroscientist Tali Sharot isolates seven factors central to influence. She shows how US President John F. Kennedy framed the space race emotionally as risk and opportunity, boosting neural synchronization and encouraging adherence to his view; and how "taming the amygdala" (the brain structure key to processing emotions) can reduce stress and susceptibility to fear-mongering.

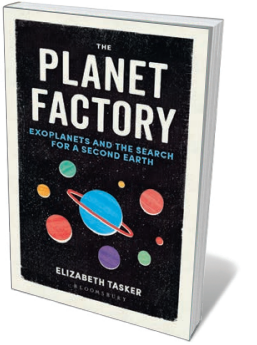

The Planet Factory: Exoplanets and the Search for a Second Earth Elizabeth Tasker BLOOMSBURY SIGMA (2017)

Astrophysicist Elizabeth Tasker expertly lassoes the fast-moving field of extrasolar-planetary science for this crisp, witty primer-plus. After a dip into planet formation and habitability, she launches into a tour of the exoplanetary zoo. Here are uninhabitable monsters such as 'lava world' 55 Cancri e and the bloated gas giant WASP-17b (with a density not far off that of expanded polystyrene). And here, too, are promising 'exo-Earths' such as Proxima Centauri b, a mere 40 trillion kilometres away. Neatly woven through are tales of discovery by the likes of planet hunter Michel Mayor. Masterful.

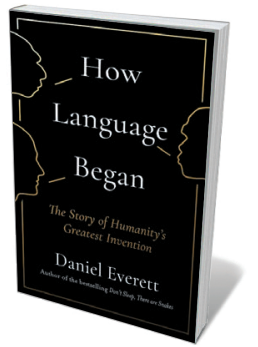

How Language Began: The Story of Humanity's Greatest Invention Daniel Everett PROFILE (2017)

Did language begin with Homo sapiens? Daniel Everett theorizes an earlier progenitor: Homo erectus, the globe-trotting hominin that lived between 2 million and 143,000 years ago. Drawing on archaeology, anthropology and neuroscience, he asserts that language is not innate, but a cultural creation that emerged synergistically through a system of invented symbols, gestures, ordering and intonation. Everett, an expert on the Amazon basin's Pirahã people, delves energetically into biological adaptations for language, the evolution of grammar and puzzles such as cross-clan communication.

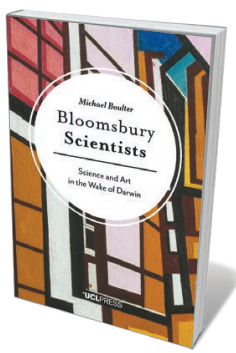

\section{Bloomsbury Scientists}

Michael Boulter UCL PRESS (2017)

Bloomsbury was famously the stomping ground of Virginia Woolf and her early-twentieth-century coterie. But that square mile centred on University College London was also a locus for science. Palaeobiologist Michael Boulter paints a group picture of biologists energized by Darwinism, including Ray Lankester and Marie Stopes, rubbing shoulders with cross-disciplinary intellects such as Roger Fry and H. G. Wells. Although marred by the intrusion of eugenics, this heady era saw the rise of fields from ecology to genetics. Barbara Kiser 